\title{
Politie in tweevoud: centraal en decentraal
}

\author{
Een analyse van enkele achtergronden en spanningen
}

\section{J. Terpstra en B. van Stokkom*}

Sinds januari 2013 kent Nederland een nationaal politiekorps. Hoewel de besluitvorming over de invoering van dit nationale politiebestel opmerkelijk snel verliep (Terpstra 2013), vormde deze beslissing de uitkomst van een al veel langer lopend proces van centralisatie en schaalvergroting van de Nederlandse politie (Fijnaut 2012). En al werd tijdens het regionaal politiebestel lange tijd het beleidsuitgangspunt 'decentraal, tenzij' beleden, in feite was al sinds midden jaren negentig sprake van een sluipende centralisatie van de Nederlandse politie (Terpstra 2004).

Opmerkelijk is dat gedurende ongeveer deze zelfde periode een tegenovergestelde beweging gaande was, namelijk van lokalisatie en decentralisatie van politieachtige werkzaamheden als toezicht en handhaving in de publieke ruimte. Rond 1990 werden in Nederland op lokaal niveau de eerste stadswachten geïntroduceerd, vaak in eerste instantie in het kader van een werkverruimende maatregel (Hauber e.a. 1994). Sinds die tijd is het aantal nieuwe toezichthoudende functionarissen gegroeid en heeft uitbreiding plaatsgevonden van hun bevoegdheden en taken. Sinds 1994 kent Nederland buitengewone opsporingsambtenaren (boa's), die ook in de publieke ruimte kunnen worden ingezet. Een belangrijke stap in dit institutionaliseringsproces werd ongeveer tien tot vijftien jaar geleden gezet, toen veel gemeenten de lokale toezichthouders en handhavers onderbrachten in speciale diensten stadstoezicht (de naam verschilt per gemeente). Sinds die tijd is een duidelijke professionalisering gaande van deze beroepsgroep. Veel

* Prof. dr. ir. Jan Terpstra is als hoogleraar Criminologie verbonden aan de Rechtenfaculteit van de Radboud Universiteit Nijmegen. Dr. Bas van Stokkom is als senior onderzoeker werkzaam bij de afdeling strafrecht van de Rechtenfaculteit van de Radboud Universiteit Nijmegen. Hij is tevens verbonden aan de afdeling Bestuurswetenschappen van de faculteit Sociale Wetenschappen van de Vrije Universiteit te Amsterdam. 
gemeenten beschikken daarmee nu over een eigen apparaat voor toezicht en handhaving op straat, waarbij geüniformeerde stadswachten en vooral ook gemeentelijke boa's in de publieke ruimte worden ingezet in winkelgebieden, uitgaanslocaties, woonwijken en bij de parkeerhandhaving (Eikenaar \& Van Stokkom 2014; Bervoets 2013). Volgens een schatting uit 2013 zouden er in Nederland 3.600 boa's werkzaam zijn in het publiek domein (Mein \& Hartmann 2013).

Met de komst van stadswachten ontstond voor gemeenten de mogelijkheid buiten de politie om te voldoen aan de groeiende roep om meer toezicht op straat. De aanwezigheid van 'eigen' gemeentelijke toezichthouders bood gemeenten bovendien een middel om zelf direct problemen met betrekking tot leefbaarheid en veiligheid aan te pakken. Gezien de toenemende politieke en beleidsmatige aandacht voor de aanpak van onveiligheid, waren ook meer en meer lokale bestuurders bereid zich daarop politiek te profileren. Rotterdam liep hier onder leiding van burgemeester Opstelten in voorop (Tops 2007). Inmiddels wordt in dit verband vaak gesproken van het ontstaan van een 'nieuwe gemeentepolitie'. Hoewel de term veelzeggend is en een grote symbolische en retorische waarde heeft, roept hij weerstand op en wordt hij vaak als niet (helemaal) accuraat ervaren (Eikenaar \& Van Stokkom 2014). Deze nieuwe gemeentelijke functionarissen beschikken immers over minder bevoegdheden dan reguliere politiemensen en hebben vaak een beperkter takenpakket. Ook ontbreekt de justitiële component in dit werk. In vergelijking met de politie hebben zij slechts in beperkte mate de beschikking over dwang- en geweldsmiddelen (Bervoets 2013; Eikenaar \& Van Stokkom 2014).

Toch valt niet te ontkennen dat in de afgelopen ruim twintig jaar, naast een centralisatie van de politie, op lokaal niveau een belangrijke ontwikkeling en herwaardering is waar te nemen in taken en functies die direct raken aan het meest elementaire onderdeel van het traditionele politiewerk, namelijk het zichtbaar aanwezig zijn op straat en zo de orde te bewaken. Juist deze taak lijkt in toenemende mate overgenomen door de nieuwe gemeentelijke toezichthouders en handhavers. Deze ontwikkeling, ook wel omschreven als een pluralisering van de politiefunctie, is overigens niet alleen in Nederland, maar in tal van Europese landen zichtbaar (Jones \& Newburn 2006; Terpstra e.a. 2013).

Met deze combinatie van enerzijds schaalvergroting, centralisatie en nationalisatie van de reguliere politieorganisatie en anderzijds het 
ontstaan op lokaal niveau van een gemeentelijke vorm van toezicht en handhaving worden de contouren zichtbaar van een duaal politiebestel. Dat roept uiteenlopende vragen op en in het hiernavolgende concentreren wij ons op twee daarvan. Ten eerste, wat zijn de belangrijkste achtergronden die hebben bijgedragen aan het ontstaan van een nieuw gemeentelijk toezicht en handhaving in de publieke ruimte, en in hoeverre hebben ontwikkelingen binnen de politie daar ook een bijdrage aan geleverd? Ten tweede, wat zijn de gevolgen van de intrede van dit duale bestel en welke nieuwe vragen roept dat op?

\section{Maatschappelijke achtergronden}

Aan de opkomst van de nieuwe gemeentelijke toezichthouders en handhavers ligt een complex van maatschappelijke, economische en politieke factoren en omstandigheden ten grondslag. Wij beperken ons hier tot de belangrijkste. Ten eerste speelt hier het sinds eind jaren tachtig toenemende belang van veiligheid en veiligheidsgevoelens een rol, zowel in maatschappelijk als in politiek opzicht. In de naoorlogse decennia steeg het criminaliteitsniveau in Nederland zeer sterk. In samenhang daarmee namen niet alleen onveiligheidsgevoelens toe, maar werden veiligheid en onveiligheidsgevoelens ook belangrijke thema's voor het overheidsbeleid. Mede om daarop een antwoord te vinden wordt in de loop van de jaren negentig een groter gewicht toegekend aan versterking van het zichtbaar toezicht en van handhaving in de publieke ruimte. De roep om 'meer blauw op straat' is een van de uitingen hiervan.

Dit hangt samen met veranderingen in onze sterk verstedelijkte samenleving, die sinds de jaren tachtig steeds meer zichtbaar worden. Veiligheid krijgt op veel centrale stedelijke locaties een grote economische betekenis. Steeds belangrijker wordt het voor de lokale op dienstverlening gerichte economie om toeristen, dagjesmensen, winkelend publiek en uitgaanspubliek te trekken. De veronderstelling daarbij is dat mensen de keuze waar zij naartoe gaan en waar zij hun geld zullen besteden, sterk laten afhangen van het veiligheidsimago van locaties. Op deze locaties wordt daarom steeds vaker een beroep gedaan op zichtbare geüniformeerde toezichthouders, waarbij het niet alleen gaat om publieke functionarissen, maar ook om private beveiligers, die zowel in de publieke als in de semipublieke ruimte worden ingezet 
(Jones \& Newburn 1999; Terpstra 2012). Vooral de ontwikkeling van grote winkelcentra, kantorenkolossen en industrieparken heeft de groei van het aantal private beveiligers bevorderd (Van Steden 2007). Nauw verwant hiermee is de groeiende economie van telkens weer terugkerende evenementen en festivals. Elke gemeente van enig belang probeert haar eigen kas en die van de lokale middenstand te spekken door naast de traditionele jaarlijkse evenementen van kermis en circus ook andere evenementen en festivals (met vaak grote aantallen bezoekers) binnen de gemeentegrenzen te krijgen, variërend van de Vierdaagsefeesten (Nijmegen) en de Aardbeienfeesten (Zundert) tot Appelpop (Tiel), Zwarte Cross (Lichtenvoorde) en de Heideweek (Ede). Ook hier is veiligheid een belangrijke voorwaarde voor succes. Daarmee wordt ook de evenementenmaatschappij (Van Steden 2009) een belangrijke bron van de groei van lokaal toezicht en handhaving, zowel publiek als privaat.

Daarnaast zijn sinds de jaren tachtig ingebouwde vormen van sociale controle in de vorm van onder meer conducteurs, conciërges en speeltuinbeheerders onder druk van bezuinigingen en efficiëntieoverwegingen vaak opgeheven (Newburn 2001). Wellicht dat hieraan, zeker in Nederland, in veel gevallen een nogal naïef mensbeeld ten grondslag lag: het vertrouwen dat burgers ook zonder daarop gecontroleerd te worden zich vanzelf wel aan de regels zouden houden. Om die reden verdwenen vanaf de jaren zeventig conducteurs uit bus, tram en trein. In een later stadium begonnen vele burgers en bestuurders zich steeds meer de negatieve consequenties hiervan te realiseren. In Nederland gebeurde dat bijvoorbeeld in de analyse van de commissie-Roethof. Deze stelde in de tweede helft van de jaren tachtig als diagnose van de sterke groei van de 'kleine' criminaliteit dat deze onder meer samenhing met het verlies van het 'functioneel toezicht'. De erkenning van dit gemis vormde vervolgens een stimulans voor invoering van de nieuwe vormen van toezicht en handhaving in de vorm van beveiligingscamera's, poortjes (op stations) en geüniformeerde toezichthouders.

Ook de groeiende anonimiteit, en het daarmee verbonden verlies van informele controle in de mobiele en verstedelijkte samenleving, speelde een rol bij de roep om meer toezicht op straat (Terpstra 2010). Enerzijds leidde dat ertoe dat bij de opkomende middenklasse de tolerantie voor stedelijk ongemak en wanorde afnam. Anderzijds hebben burgers in een anonieme samenleving, gekenmerkt door zwakke soci- 
ale banden en weinig onderlinge familiariteit (Blokland 2009), vaak weinig bereidheid en vermogen om zelf kleine problemen van overlast en wanorde aan te pakken en op te lossen. Als het de middenklasse niet lukt de stedelijke wanorde te vermijden (bijvoorbeeld door in de veilige suburbs of plattelandsdorpen te gaan wonen) (Emmelkamp 2004), wordt in een door formele organisaties gedomineerde samenleving de oplossing voor deze problemen verwacht van gespecialiseerde instanties en beroepsgroepen. Ook dit lijkt een van de achtergronden van de roep om meer toezicht en handhaving op straat.

\section{Politie en de groei van gemeentelijk toezicht}

Een belangrijke vraag in dit verband is welke rol de politie in Nederland heeft gespeeld in het ontstaan en de groei van lokaal toezicht en handhaving. Deze vraag is des te relevanter omdat nog niet lang geleden zichtbaar toezicht en handhaving werden beschouwd als de kern van het politiewerk. In de woorden van de vroegere Amsterdamse korpschef Jelle Kuiper (2004, p. 175): de taak van de politie is vooral 'om er eenvoudig te zijn', om zo 'te waken tegen het kwaad' en dat tegen te houden.

Een vaak geuite veronderstelling is - zie onder andere het Beleidsplan Nederlandse Politie 1999-2002 (voor een overzicht, zie Terpstra e.a. 2010) - dat de politie niet meer zou toekomen aan deze taken, omdat de hoeveelheid werk waarmee zij wordt geconfronteerd almaar zou zijn toegenomen, terwijl de politie over steeds minder middelen beschikt. Hoe populair deze verklaring ook is (zij het meer in beleidskringen dan op de politiële werkvloer), erg plausibel is zij niet. Ten eerste, er is altijd meer vraag naar politiewerk dan waar deze organisatie aan kan voldoen. In die zin kan de politie zich niet achter dit noodlot verschuilen. Er is bij de politie altijd sprake van keuzes op welke thema's de aandacht moet worden gericht en waarvoor de middelen moeten worden ingezet.

Ten tweede, de genoemde veronderstelling - en vooral de aanname dat de politie over minder middelen beschikt - rammelt ook feitelijk. Tussen 1980 en 2011 is de hoeveelheid mensen die bij de Nederlandse politie werken vrijwel constant gegroeid (Terpstra 2010, p. 41). Alleen al in de periode tussen 1994 en 2009 nam de formatieve sterkte van de Nederlandse politie toe met $29 \%$ (Haagsma e.a. 2012). Van belang is 
hoe die ontwikkeling zich verhoudt tot de veranderingen in de omvang van de criminaliteit. Vanaf de jaren vijftig en zestig groeide het niveau van de criminaliteit in Nederland sterk: tussen 1960 en 2002 nam de geregistreerde criminaliteit met een factor zeven toe, rekening houdend met de groei van de Nederlandse bevolking in die periode (Eggen e.a. 2003). Echter, vanaf laatstgenoemd jaar is het niveau van criminaliteit in ons land substantieel en voortdurend afgenomen. Tussen 2005 en 2013 daalde het niveau van de criminaliteit in Nederland met ongeveer 30\% (Vergouw e.a. 2014). Desalniettemin is de groei van de Nederlandse politie tot 2011 blijven toenemen. Het is dan ook niet verwonderlijk dat de stelling dat de Nederlandse politie onderbezet is, door de journalist Bart de Koning (2012) wordt gerekend tot een van de hardnekkige mythes in het Nederlandse veiligheidsbeleid. De opgetreden groei van gemeentelijk toezicht en handhaving op straat kan dan ook moeilijk worden verklaard uit de omstandigheid dat de politie te weinig menskracht zou hebben om deze taken uit te voeren. De verklaring moet elders worden gezocht. Verschillende factoren en ontwikkelingen rond de Nederlandse politie over de afgelopen decennia zijn daarbij van belang.

Zoals eerder aangegeven, is sinds begin jaren negentig sprake van schaalvergroting en centralisatie van de Nederlandse politie. Met de komst van het regionaal politiebestel verdwenen behalve de gemeentepolitie ook de lokale posten van de Rijkspolitie, die in bijna alle dorpen aanwezig waren. Vooral op het platteland wordt sinds die tijd geconstateerd dat de politie op grotere afstand is komen te staan. Bekend zijn de terugkerende klachten over aanrijtijden van de politie in landelijke gebieden. Onder meer vanwege centrale beleidsprioriteiten en prestatieafspraken met de politiekorpsen nam de invloed van het centrale-rolniveau verder toe. Rond 2000 werd in de politieregio Utrecht in onderzoek geconstateerd dat er een verschuiving plaatsvond van politiepersoneel van de landelijke gebieden naar de stedelijke. Kleine plattelandsgemeenten probeerden de gaten die op deze wijze ontstonden in het lokaal toezicht en handhaving zelf op te vangen, bijvoorbeeld door uit eigen middelen zogenaamde politiesurveillanten of extra wijkagenten te betalen. Naast dit extra politiepersoneel (betaald door de gemeente en alleen in te zetten in het eigen gebied voor aangewezen taken) gingen deze kleine gemeenten vaker over op het aanstellen van toezichthouders en boa's in dienst van de gemeente (Terpstra 2002; Gemeente Haaksbergen 2006). Deze ontwikkeling was 
des te opvallender omdat met de komst van het regionaal politiebestel een sterke stimulans werd gegeven aan het gebiedsgebonden politiewerk, mede om de hier en daar gevreesde negatieve gevolgen voor het lokaal politiewerk tegen te gaan.

Hiernaast werd nog een tweede terugtrekkende beweging van de politie zichtbaar. Ondanks de toename van de hoeveelheid personeelsleden heeft de Nederlandse politie zich gedurende ongeveer de afgelopen twee decennia steeds meer teruggetrokken van het zichtbare toezicht op straat. Uit de studie van Haagsma en collega's (2012, p. 47) blijkt dat tussen 1999 en 2009 de formatie die beschikbaar is voor de basispolitiezorg en het wijkwerk met ongeveer $8 \%$ daalde, terwijl in deze zelfde periode de capaciteit voor de recherche bijna verdubbelde. Deze veranderingen houden onder meer verband met de sterkere concentratie van de Nederlandse politie op haar zogenaamde kerntaken. Zowel het meer bedrijfsmatig denken bij de politie als een groeiende politieke en maatschappelijke vraag om een 'harde' aanpak droeg hieraan bij. De eerste signalen van deze omslag werden zichtbaar aan het begin van deze eeuw. In de paarse kabinetsnota Criminaliteitsbeheersing werd strafrechtelijke handhaving als dé kerntaak genoemd van de politie. Steeds vaker werd de opvatting naar voren gebracht dat de politie zich te veel met 'oneigenlijke taken' zou bezighouden en zou moeten 'terugkeren' naar haar kerntaken. Daaronder werden vaak handhaving en opsporing verstaan.

In de praktijk bleek het echter lastig tot een afbakening van deze kerntaken te komen. In 2004 komt de regering met een zogenaamde Kerntakenbrief: alleen die taken die de inzet van geweld of dwangmiddelen met zich meebrengen, zouden moeten worden gezien als politiewerk. Uiteindelijk ziet de regering echter in 2005 met de Notitie Kerntaken af van een inperking of herdefiniëring van deze kerntaken. Ook in de nieuwe Politiewet 2012 blijft de omschrijving van de taak van de politie ongewijzigd. Ook al lijkt daarmee de kerntakendiscussie afgelopen en weinig concreets te hebben opgeleverd, de gedachte dat de politie zich zou moeten concentreren op een beperkt aantal kerntaken lijkt nog springlevend. Hoewel de regering afzag van inperking van de kerntaken, heeft deze opvatting binnen de politie vaak nog de status van een vanzelfsprekend dogma (Terpstra e.a. 2010).

Vele gemeenten constateren dan ook dat de politie onder het mom van een concentratie op vermeende kerntaken het toezicht en handhaving op straat vaak laat liggen. Eerst waren de fout geparkeerde 
auto's geen politiewerk meer, toen waren gevaarlijke verkeerssituaties rond scholen geen thema meer, vervolgens liet de politie de burenruzies liggen, daarna werd niet meer gereageerd op overlast door groepen jongeren in woonwijken, toen hoorden bedreigingen bij scholen en cafés er niet meer bij, waarna ook winkeldiefstal meer een probleem van de winkelier werd, en zo is de lijst nog eindeloos te verlengen. Het afschuiven van de blijkbaar als oninteressant beschouwde toezichts- en handhavingstaken op straat lijkt vooral ingegeven door een combinatie van een traditionele politiecultuur met een professionaliseringsproces binnen deze organisatie. Het eerste maakt dat de politie vaak liever spannende dingen doet. Het tweede maakt dat men liever professioneel interessantere werkzaamheden verricht. De combinatie maakt dat het 'eenvoudige' preventieve toezicht op straat met enig dedain terzijde is geschoven.

Ook in het beleid wordt deze ontwikkeling onderkend, zij het dat deze eerder als een uitdaging voor gemeenten lijkt te worden opgevat. In de toelichting op de Boa circulaire 2013 wordt het volgende geconstateerd:

'De afgelopen jaren is een tendens waarneembaar dat de politie (...) zich meer gaat richten op de kerntaken en de gemeenten steeds meer mogelijkheden krijgen om de taken die de politie niet langer als kerntaak ziet, op te pakken.' (p. 4)

En:

‘De rol van boa’s bij de strafrechtelijke handhaving wordt groter. Zij nemen steeds meer taken van de politie over.' (p. 5)

Het lijkt hier te gaan om wat Goffman (1963) in een ander verband secondary gains noemde: wat begon als het afschuiven van werk door de politie, bleek voor de gemeenten niet alleen een probleem, maar ook voordelen te kunnen hebben. Zij konden vanaf nu zelf bepalen waar toezicht en handhaving moeten worden ingezet, zonder moeizame onderhandelingen met de politie.

De komst van de Nationale Politie per januari 2013 sluit voor een belangrijk deel aan bij de hier geschetste ontwikkelingen. Daarbij doen zich op het eerste gezicht tegenstrijdige ontwikkelingen voor. Enerzijds is sprake van schaalvergroting en centralisatie. Bij de vorm- 
geving van de Nationale Politie ligt veel nadruk op uniformering en standaardisatie van werkprocessen en organisatie. Het laagste niveau van de organisatie bestaat uit basisteams, verantwoordelijk voor alle niet-specialistische politietaken in hun werkgebied. Deze basisteams zijn in de regel aanzienlijk groter dan de teams bij de politie in het verleden.

Tegelijk wordt de komst van de Nationale Politie gepresenteerd als versterking van de lokale inbedding van de politie. Juist doordat meer capaciteit ter beschikking staat, zou een 'robuuster' basis voor het operationele lokale politiewerk ontstaan, niet meer afgeleid door beheerszaken en de 'bestuurlijke drukte' van het regionaal bestel. Niet iedereen lijkt op voorhand overtuigd van deze belofte. Een van de weinige concrete maatregelen ter versterking van het lokaal politiewerk bestaat uit de (door de Tweede Kamer afgedwongen) wettelijke norm dat er op elke 5.000 inwoners één wijkagent dient te zijn. Ruim twee jaar na de start van de Nationale Politie blijft het, mede vanwege de vele vertragingen in het reorganisatieproces, in vele opzichten onduidelijk hoe de lokale gevolgen van de Nationale Politie in de praktijk zullen uitpakken (Inspectie Veiligheid en Justitie 2014, 2015). Uit de eerste studie van de Inspectie blijkt dat het in de nieuwe organisatie lastig blijft een evenwicht te vinden tussen centrale sturing en lokaal maatwerk (Inspectie 2013, p. 46). De beperkte hoeveelheid onderzoek die tot nu toe is verricht, geeft aan dat de diversiteit op lokaal niveau ook binnen het nationaal bestel groot blijft (Terpstra \& Fyfe 2015).

Ook al zouden binnen de basisteams behoorlijk meer wijkagenten worden aangesteld dan in het verleden het geval was, dan nog is het de vraag in hoeverre dat de maatschappelijke inbedding van de politie ten goede zou komen. Er zijn veel signalen dat wijkagenten meer en meer opsporings- en noodhulpwerkzaamheden binnen hun basisteam verrichten en relatief weinig contact hebben met burgers (Terpstra 2008; Van Caem 2011). Aan het gebrekkige preventieve toezicht op straat zal de komst van meer wijkagenten sowieso weinig kunnen veranderen.

Mede vanwege de vertragingen in het reorganisatieproces zullen veel gemeenten nog slechts in beperkte mate te maken hebben gehad met de gevolgen van de schaalvergroting en centralisatie. Veelzeggend is echter de bevinding uit een nog lopend Nijmeegs onderzoek dat veel gemeenten verwachten dat zij in de naaste toekomst meer boa's 
(eventueel in de vorm van private beveiligers) in zullen moeten zetten om de gaten in toezicht en handhaving op te vullen die de Nationale Politie in hun ogen op dit punt laat vallen.

\section{Vragen en risico's}

De sterke opmars in de afgelopen 25 jaar van gemeentelijke toezichthouders en handhavers in combinatie met een terugtrekkende beweging van de politie roept een groot aantal vragen op. In de afgelopen jaren zijn in Nederland de contouren ontstaan van een duaal politiebestel. Aan de ene kant staat een nationale, gecentraliseerde en omvangrijke politieorganisatie met vele bevoegdheden en faciliteiten die zich vooral lijkt te gaan richten op opsporing en de 'harde' handhaving. Daartegenover staan vaak kleine lokale toezichts- en handhavingsdiensten, qua omvang variërend van enkele medewerkers tot enige tientallen. Zij beschikken over een beperkte hoeveelheid bevoegdheden en faciliteiten. Terwijl de Nationale Politie wel de middelen en bevoegdheden heeft, lijkt zij meer op afstand van de burgerij te komen. Aan de andere kant staan de gemeentelijke toezichthouders en handhavers dichter bij de lokale samenleving en bestuur.

Een van de belangrijkste risico's van dit duale bestel is de fragmentering ervan (Van Steden 2012). Ondanks de komst van een Nationale Politie dreigt zo voor burgers en partners opnieuw een onoverzichtelijk geheel te ontstaan. Hoe zijn de verschillende uniformen uit elkaar te halen? Waarom richt de een zich op het vangen van de boef en de ander op de handhaving van de kleine norm? De vraag is ook welke gevolgen deze onoverzichtelijkheid heeft voor het imago van beide partijen en voor hun geloofwaardigheid. In het geval van lokale toezichthouders en handhavers speelt bovendien nog hun vaak wat negatieve imago een rol, wat vooral een gevolg is van het verleden, waarin zij werden geassocieerd met projecten voor langdurig werklozen (Bervoets 2013; Eikenaar \& Van Stokkom 2014; Terpstra 2012). Mogelijk draagt dit ook bij aan de onduidelijkheid voor veel burgers over wat zij van deze toezichthouders en handhavers kunnen verwachten (Van Steden e.a. 2009).

Daarnaast moet worden geconstateerd dat veel van de gemeentelijke toezichts- en handhavingsdiensten tamelijk kwetsbaar zijn. Dat heeft niet alleen te maken met de schaal waarop zij moeten functioneren, 
die vooral in kleinere gemeenten vaak beperkt is. De kwetsbaarheid blijkt ook nu de laatste paar jaar gemeenten worden geconfronteerd met aanzienlijke bezuinigingen. Hoewel gemeenten in de regel overtuigd zijn van de belangrijke functie die deze gemeentelijke diensten vervullen, juist ook om de gaten op te vullen die de politie laat vallen, zien zij zich vaak genoodzaakt ook hier de geldkraan gedeeltelijk dicht te draaien. De per 1 januari 2015 afgeschafte vergoeding voor door gemeentelijke boa's uitgeschreven processen-verbaal heeft in sommige gemeenten geleid tot een inkrimping van het aantal gemeentelijke handhavers.

Bij een gefragmenteerd politiebestel zoals dat nu bestaat, is uiteraard de vraag van belang hoe hierbinnen de coördinatie of regie is geregeld. In Nederland heeft deze regie een merkwaardige vorm gekregen. De politie heeft de zogenaamde operationele regie over de gemeentelijke toezichthouders en boa's in de publieke ruimte. Het is opmerkelijk dat deze operationele regie bij de politie ligt, terwijl de beleidsmatige regie bij de gemeente berust. Bovendien is de burgemeester gezagdrager over de lokale politie voor zover het openbareordehandhaving en dienstverleningstaken betreft. Daarnaast worden de stadswachten en boa's door de gemeente betaald, niet door de politie. Overigens blijkt in de praktijk dat deze operationele regie meer in handen ligt van de gemeente dan van de politie (Bervoets 2013; Van Stokkom \& Eikenaar 2014). Maar belangrijker, het claimen door de politie van deze operationele regietaak komt weinig geloofwaardig over als ondertussen deze zelfde politie zich probeert terug te trekken van toezicht en handhaving in de publieke ruimte (Van Stokkom \& Eikenaar 2014). In de vroege jaren negentig probeerde de politie door het aanstellen van politiesurveillanten met een alternatief te komen voor gemeentelijke stadswachten en handhavers. Zij hoopte op deze wijze de fragmentering van dit veld te voorkomen. Hoe lovenswaardig dit initiatief ook was, de steun binnen de Nederlandse politie hiervoor was zo gering, dat dit alternatief bijna geheel uit de collectieve herinnering is verdwenen.

Met de ontwikkeling van lokale toezichthouders en handhavers komt nadrukkelijker de vraag naar voren hoe het zit met hun bevoegdheden, taken en dwang- en geweldsmiddelen. Er is sprake van een geleidelijke uitbreiding van taken, bevoegdheden en dwangmiddelen. Het past in de ontwikkeling waarin de gemeente stap voor stap toch een eigen politie krijgt. De continue discussie over hoe ver met deze taak- en 
bevoegdheidsuitbreiding moet worden doorgegaan en in hoeverre meer geweldsmiddelen moeten worden toegekend, dreigt daardoor telkens weer door de feiten te worden ingehaald.

\section{Slot: een korte blik naar de toekomst}

Politiehervormingen hebben de neiging elkaar in hoog tempo op te volgen (Wennström 2013). In dit verband spreekt Brodeur (2005) van een neiging tot een permanente politiehervorming, oftewel Trotsky in Blue. Of het in Nederland deze keer ook zo zal gaan, is voorlopig afwachten. Het vorige politiebestel hield het nog geen twintig jaar uit. Hoe dat ook zij, Nederland zal het een tijdje met dit bestel moeten doen.

Als over pakweg tien jaar een buitenlander Nederland bezoekt om te kijken wat voor politiebestel wij hebben, zal het niet eenvoudig zijn uit te leggen waarom wij in Nederland een politie in tweevoud hebben, twee naast elkaar bestaande soorten organisaties voor policing taken. Naast één gecentraliseerd landelijk korps voor de 'harde' politietaken is er dan een groot aantal (maar waarschijnlijk geen bijna vierhonderd meer) lokale 'politiekorpsen' met een beperkt mandaat, maar ook met een vermoedelijk vriendelijker imago. De buitenlandse bezoeker zal verbaasd aanhoren dat in 2012 in Nederland een ingrijpende politiehervorming plaatsvond, unaniem gesteund door de Tweede Kamer, waarin besloten werd tot één nationaal korps. De les zal vermoedelijk zijn dat de politiek besloot tot één korps, maar dat - achter de rug om van landelijke politiek en beleid - het politielandschap feitelijk ging bestaan uit enige honderden policing diensten.

Een van de vele vragen die deze ontwikkelingen oproepen, is wat te denken van de taakverdeling die nu lijkt te ontstaan tussen de twee soorten politie in Nederland. Krijgen wij een Nationale Politie voor het 'echte' politiewerk, dat wil zeggen het werk met justitiële elementen en waarbij dwangmiddelen moeten worden ingezet? Wat betekent dat voor het imago, de legitimiteit en de interne cultuur van beide typen politiekorpsen? Wat betekent dat op lange termijn, als de gemeentelijke diensten steeds meer taken op zich moeten nemen, zonder dat zij over voldoende middelen beschikken om hun werk en hun organisatie uit te bouwen? Krijgen wij zo twee organisaties, de eerste op afstand, maar voor burgers alleen zichtbaar als hard moet worden opgetreden, 
de tweede benaderbaar en zichtbaar, maar zonder mogelijkheden op te treden als dat nodig is?

Te vrezen valt dat met deze dualisering van het politiebestel het kenmerkende van politiewerk verloren gaat, namelijk beschikbaar zijn om direct problemen op te kunnen lossen, altijd tegen de achtergrond van het besef dat dwang kan worden ingezet. Tegelijkertijd dreigt de politie haar geloofwaardigheid te verspelen door minder zichtbaar op straat aanwezig te zijn en de boodschap af te geven dat handhaving van de 'kleine norm' een oneigenlijke taak zou zijn. Ook de politie moet haar gezag in de openbare ruimte zien te verdienen (Crijns 2010). Bovendien wordt haar kennis over onveiligheid en criminaliteit door alledaagse contacten met burgers gevoed. De meeste politiemensen voelen dit - de terugtred naar de kerntaken ten spijt - goed aan: kennen en gekend worden is van wezenlijk belang voor het politiewerk.

\section{Literatuur}

\section{Bervoets 2013}

E. Bervoets, Gemeentelijk blauw. Het dagelijks werk van gemeentelijke handhavers in beeld, Apeldoorn/Rotterdam: Politie en Wetenschap/Lokale Zaken 2013.

\section{Blokland 2009}

T. Blokland, Oog voor elkaar. Veiligheidsbeleving en sociale controle in de grote stad, Amsterdam: Amsterdam University Press 2009.

\section{Brodeur 2005}

J.P. Brodeur, 'Trotsky in Blue: Permanent policing reform', The Australian and New Zealand Journal of Criminology (38) 2005, afl. 2, p. 254-267.

\section{Van Caem 2011}

B. van Caem, Buurtregie met mate: over de spanning tussen nabijheid en distantie in de relatie tussen politie en burgers, Den Haag: Boom Lemma uitgevers 2011.

\section{Crijns 2010}

J.H. Crijns, 'Een terugtocht van de politie uit de openbare ruimte?', Strafblad 2010, afl. 5, p. 376-386.

\section{Eggen e.a. 2003}

A.Th.J. Eggen, M. Kruissink \& P. van Panhuis, 'Criminaliteit en opsporing', in: W. van der Heide \& A.Th.J. Eggen (red.), Criminaliteit en rechtshandhaving 2001. Ontwikkelingen en beleid, Den Haag: WODC 2003, p. 81-108. 


\section{Eikenaar \& Van Stokkom 2014}

T. Eikenaar \& B. van Stokkom, Van stadswacht naar gemeentepolitie? Gemeentelijk toezicht en handhaving in de openbare ruimte, Apeldoorn: Politie \& Wetenschap 2014.

\section{Emmelkamp 2004}

R. Emmelkamp, 'Opgroeiende jongeren en veiligheid in stand en platteland: de zorgen van ouders ontrafeld', Beleid en Maatschappij (31) 2004, afl. 3, p. 185-193.

\section{Fijnaut 2012}

C. Fijnaut, Het Nationale Politiekorps, Amsterdam: Uitgeverij

Bert Bakker 2012.

\section{Gemeente Haaksbergen 2006}

Gemeente Haaksbergen, Veiligheidsbeeld 2005, 2006.

\section{Goffman 1963}

E. Goffman, Stigma: Notes on the management of spoiled identity, Englewood Cliffs, NJ: PrenticeHall 1963.

\section{Haagsma e.a. 2012}

J. Haagsma e.a., De sterkte van de arm: feiten en mythes, Apeldoorn: Politie \& Wetenschap 2012.

\section{Hauber e.a. 1994}

A.R. Hauber e.a., Stadswachten: effectiviteit, draagvlak en organisatorische aspecten, Den Haag: Ministerie van Justitie 1994.

\section{Inspectie Veiligheid en Justitie} 2013

Inspectie Veiligheid en Justitie, Nationale Politie op koers? Eerste onderzoek naar de mijlpalen en resultaten van acht operationele doelen in de periode 1 januari-1 juli 2013, Den Haag 2013.

\section{Inspectie Veiligheid en Justitie} 2014

Inspectie Veiligheid en Justitie, Tweede onderzoek vorming nationale politie. Operationele doelen periode 1 juli 2013-1 januari 2014. Bevoegd gezag periode 2013, Den Haag 2014.

\section{Inspectie Veiligheid en Justitie 2015}

Inspectie Veiligheid en Justitie, Derde onderzoek vorming nationale politie. Onderzoek naar het in werking brengen van basisteams en districtsrecherche per 1 januari 2015, Den Haag 2015. Jones \& Newburn 1999

T. Jones \& T. Newburn, 'Urban change and policing: Mass private property re-considered', European Journal on Criminal Policy and Research (7) 1999, afl. 2, p. 225-244.

\section{Jones \& Newburn 2006}

T. Jones \& T. Newburn, 'Understanding plural policing', in: T. Jones \& T. Newburn (red.), Plural policing: A comparative perspective, Londen: Routledge 2006, p. 1-11. 


\section{De Koning 2012}

B. de Koning, De veiligheidsmythe. Over politie, justitie en misdaad in Nederland, Amsterdam: Balans 2012.

\section{Kuiper 2004}

J. Kuiper, Rust'loos wakend, Alphen aan den Rijn: Kluwer 2004.

\section{Mein \& Hartmann 2013}

A. Mein \& A.R. Hartmann, De stand van het boa-bestel: eindrapport over het stelsel waarbinnen buitengewone opsporingsambtenaren functioneren, Utrecht: Verwey-Jonker Instituut 2013.

\section{Newburn 2001}

T. Newburn, 'The commodification of policing: Security networks in the late modern city', Urban Studies (38) 2001, afl. 5-6, p. 829-848.

\section{Van Steden 2007}

R. van Steden, Privatizing policing: Explaining the growth of private security, Den Haag: Boom Juridische uitgevers 2007.

\section{Van Steden 2009}

R. van Steden, 'De pretparksamenleving. Een wereld van veilig vertier', in: H. Boutellier (red.), Omstreden ruimte. Over de organisatie van spontaniteit en veiligheid, Amsterdam: Van Gennep 2009, p. 15-31.

\section{Van Steden 2012}

R. van Steden, Veelvormig en versnipperd: gemeentelijke toezichthouders en handhavers in het publieke domein, Amsterdam/ Den Haag: Vrije Universiteit/ SMVP 2012.

\section{Van Steden e.a. 2009}

R. van Steden, M. Roelofs \& M. Nalla, 'Burgers over beveiligers. Een kwantitatief onderzoek naar percepties, verwachtingen en oordelen', Tijdschrift voor Veiligheid (8) 2009, afl. 4, p. 3-21.

\section{Van Stokkom \& Eikenaar 2014}

B. van Stokkom \& T. Eikenaar, 'Boa's: een volwaardige beroepsgroep naast de politie?', Tijdschrift voor de Politie 2014, afl. 7, p. 6-10.

\section{Terpstra 2002}

J. Terpstra, Sturing van politie en politiewerk. Een verkennend onderzoek tegen de achtergrond van een veranderende sturingscontext en sturingsstijl, Zeist: Kerckebosch 2002.

\section{Terpstra 2004}

J. Terpstra, 'Lokale inbedding van de Nederlandse politie: stand van zaken en overzicht', in: F. Vlek e.a. (red.), Uit balans: politie en bestel in de knel. State-of-the-art van kennis en inzichten, Zeist/ Apeldoorn: Kerckebosch/Politie \& Wetenschap 2004. 


\section{Terpstra 2008}

J. Terpstra, Wijkagenten en hun dagelijks werk: een onderzoek naar de uitvoering van gebiedsgebonden politiewerk, Apeldoorn: Politie \& Wetenschap 2008.

\section{Terpstra 2010}

J. Terpstra, Het veiligheidscomplex. Ontwikkelingen, strategieën en verantwoordelijkheden in de veiligheidszorg, Den Haag: Boom Juridische uitgevers 2010.

\section{Terpstra 2012}

J. Terpstra, 'Particuliere beveiligers als publieke handhavers. De inzet van private boa's door gemeenten', Justitiële verkenningen (38) 2013, afl. 8, p. 35-50.

\section{Terpstra 2013}

J. Terpstra, 'Towards a national police in the Netherlands - backgrounds of a radical police reform', in: N. Fyfe, J. Terpstra \& P. Tops (red.), Centralizing forces?, Den Haag: Eleven International Publishing 2013, p. 137-155.

\section{Terpstra \& Fyfe 2015}

J. Terpstra \& N. Fyfe, 'Mind the implementation gap? Police reform and local policing in the Netherlands and Scotland', Criminology and Criminal Justice, DOI: 10.1177/1748895815572162.

\section{Terpstra e.a. 2010}

J. Terpstra, L. Gunther Moor \& B. van Stokkom, 'De kerntakendiscussie in Nederland. Retoriek en realiteit', in: B. van Stokkom, J. Terpstra \& L. Gunther Moor (red.), De politie en haar opdracht. De kerntakendiscussie voorbij, Antwerpen: Maklu 2010, p. $25-50$.

\section{Terpstra e.a. 2013}

J. Terpstra, B. van Stokkom \& R. Spreeuwers, Who patrols the streets? An international comparative study to plural policing, Den Haag: Eleven International Publishing 2013.

\section{Tops 2007}

$\mathrm{P}$. Tops, Regimeverandering in Rotterdam. Hoe een stadsbestuur zich opnieuw uitvond, Amsterdam: Atlas 2007.

\section{Vergouw e.a. 2013}

S.J. Vergouw, R.P.W. Jennissen, G. Weijters \& P.R. Smit, Resultaten van de Nationale Veiligheidsindices 2013 (Factsheet 2014-6), Den Haag: WODC 2013.

\section{Wennström 2013}

B. Wennström, 'Police reform in Sweden: How to make a perfect cup of espresso', in: N. Fyfe, J. Terpstra \& P. Tops (red.), Centralizing forces?, Den Haag: Eleven International Publishing 2013, p. 157-172. 